\title{
Investigation of the immobilisation/mobilisation of nickel, copper, chromium and zinc following co-disposal of activated sewage sludge with synthetic refuse
}

\author{
George AC Ehlers ${ }^{1 *}$, Richard A Daneel ${ }^{2}$ and Eric Senior ${ }^{3}$ \\ ${ }^{1}$ Department of Biochemistry and Microbiology, Rhodes University, PO Box 94, Grahamstown 6140, South Africa \\ ${ }^{2}$ International Centre for Waste Technology (Africa), School of Applied Environmental Sciences, University of Natal, Private Bag X01, \\ Scottsville, Pietermaritzburg 3209, South Africa \\ ${ }^{3}$ Environmental Technology Institute, Innovation Centre (NTU), 18 Nanyang Drive; 637723, Singapore
}

\begin{abstract}
Laboratory microcosms were packed with synthetic refuse and waste activated sewage sludge in two ratios $(4.1: 1$ and $4.1: 2 \mathrm{v} / \mathrm{v})$. The sludge was spiked $\left(\left.100 \mathrm{mg} \cdot\right|^{-1}\right.$ or $\left.\left.200 \mathrm{mg} \cdot\right|^{-1}\right)$ with the salts of each of four heavy metals $\left(\mathrm{Ni}^{2+}, \mathrm{Cu}^{2+}, \mathrm{Cr}^{3+}\right.$ and $\left.\mathrm{Zn}^{2+}\right)$. Subsequently, the metal concentrations were increased progressively. For all the microcosms, including an unperturbated control, unbalanced fermentations resulted as evidenced by low $\mathrm{pH}$ values. Thus, heavy metal presence was not the sole cause. The leached metal concentrations were in a consistent order with high $\mathrm{Zn}$ and $\mathrm{Ni}$ concentrations recorded compared with immobilised $\mathrm{Cr}$ and $\mathrm{Cu}$. After 15 weeks of operation, despite extensive retention, increases in $\mathrm{Cr}, \mathrm{Ni}$ and $\mathrm{Zn}$ were detected in the leachates following elevated loadings. Due to the high redox potentials $(+2$ to $+170 \mathrm{mV})$, precipitation of the metals as insoluble sulphides was not attainable.
\end{abstract}

\section{Introduction}

Heavy metals are present in a range of industrial wastes together with industrial and household products. They are, therefore, components of household refuse (Knox, 1989). Since there is a wide variety in the chemical and environmental behaviour of heavy metals (Knox,1989), their fates in co-disposal landfills are of concern (Gregson et al., 1988).

In co-disposal landfills, potential heavy metal toxicities to micro-organisms may be maximised or minimised depending on the metal-binding capacity of a particular sludge (MacNicol and Beckett, 1989), the ion and organic constituent interactions (Babich and Stotzky, 1985; Fletcher and Beckett, 1987) and the specific dissolved metal species present and their concentrations (Mueller and Steiner, 1992).

This picture can be complicated further by the application of covering soil between the refuse cells and, more particularly, by the activity of microbial catabolic species. Clayey impermeable material, for example, is dominated by fermentative populations while respiratory microbial species attach to the more sandy soils (Chapelle, 1993). The former species catabolise complex organic molecules and release intermediates which, in turn, are oxidised by respiratory species by reducing available electron acceptors (oxygen, nitrate, manganese hydroxides, iron hydroxides, sulphate and carbon dioxide). As a consequence, redox gradients are generated. Heavy metal precipitations as sulphides are related indirectly to redox potential. Such precipitations play a key role in the immobilisation of heavy metals in the refuse mass.

For this investigation of immobilisation/mobilisation of heavy metals following co-disposal operation, four species $\left(\mathrm{Ni}^{2+}, \mathrm{Cu}^{2+}\right.$,

\footnotetext{
* To whom all correspondence should be addressed.

讯(046) 603-8446; fax: (046) 622-3984;

e-mail: g00E3721@ campus.ru.ac.za

Received 12 September 2000; accepted in revised form 1 August 2001.
}

$\mathrm{Cr}^{3+}$ and $\mathrm{Zn}^{2+}$ ) were chosen on the basis of their variable mobilities and presence in refuse and sewage sludge.

\section{Materials and methods}

\section{Refuse}

A synthetic refuse was prepared by combining equal volumes of shredded paper from a paper recycling plant and vegetable plus garden wastes. The moisture content of the refuse was determined by taking two samples ( $100 \mathrm{~g}$ each) and drying at $60^{\circ} \mathrm{C}$ for $72 \mathrm{~h}$. The samples were weighed before and after drying and the moisture content was determined by the mass difference.

\section{Sewage sludge}

Activated sewage sludge was collected from the return channel of Darvill Sewage Works, Pietermaritzburg. The moisture content was determined as above after drying at $70^{\circ} \mathrm{C}$.

\section{Microcosm construction and operation of microcosms}

Six glass columns (length $50 \mathrm{~cm}$, i.d. $5.3 \mathrm{~cm}$ ) were used (Percival and Senior, 1998). The microcosms were packed with synthetic refuse \pm sewage sludge (Table 1$)$. Two refuse:sewage sludge packing ratios of, 4.1:1 and 4.1:2 (v/v) were used (Percival, 1996), while the refuse-packing density was $\sim 830 \mathrm{~kg} \cdot \mathrm{m}^{-3}$.

Glass wool was placed at the base of each column to prevent refuse/sludge displacement. The columns were incubated in the dark at $30^{\circ} \mathrm{C}$ in a temperature-controlled box fitted with heating elements. Fermentation gases were vented from the microcosms via $\mathrm{Zn}$ acetate $(0.1 \% \mathrm{~m} / \mathrm{v})$ gas traps to collect hydrogen sulphide as insoluble zinc sulphide. Leachate was recycled daily by removing $40 \mathrm{ml}$ from the base of each microcosm with a hypodermic needle connected to a plastic syringe (20 I) and reintroducing it to the top of the column. 


\begin{tabular}{|c|l|l|}
\hline \multicolumn{2}{|c|}{ TABLE 1 } \\
Microcosm packing materials and initial heavy metal loading \\
\hline $\begin{array}{c}\text { Micro- } \\
\text { cosm }\end{array}$ & $\begin{array}{l}\text { Packing } \\
\text { materials }\end{array}$ & Heavy metal loading \\
\hline 1 & Refuse + sludge $(4.1: 1)$ & Heavy metal spiked sludge $\left(100 \mathrm{mg} \cdot \mathrm{l}^{-1}\right)$ \\
2 & Refuse + sludge $(4.1: 1)$ & Sludge not spiked \\
3 & Refuse + sludge $(4.1: 2)$ & Heavy metal spiked sludge $\left(200 \mathrm{mg} \cdot \mathrm{l}^{-1}\right)$ \\
4 & Refuse + sludge $(4.1: 2)$ & Sludge not spiked \\
5 & Refuse & $\mathrm{dH}_{2} 0$ plus heavy metal $\left(200 \mathrm{mg} \cdot \mathrm{I}^{-1}\right)$ \\
6 & Refuse & $\mathrm{dH}_{2} 0$ \\
\hline
\end{tabular}

Microcosms 3 and 5, week 13;400 mg. $\left.\right|^{-1}$, Microcosm 1 and $\left.800 \mathrm{mg} \cdot\right|^{-1}$, Microcosms 3 and 5, week 14; and $800 \mathrm{mg} \cdot \mathrm{l}^{-1}$, Microcosm 1 and $1600 \mathrm{mg} \cdot \mathrm{I}^{-}$, Microcosms 3 and 5, week 15. The unspiked microcosms received equivalent volumes of $\mathrm{dH}_{2} \mathrm{O}$ at each dosage point.

\section{Analyses}

\section{$\mathrm{pH}$}

A Crison MicropH 2002 meter fitted with a $\mathrm{pH}$ electrode (Ingold) was used to determine the supernatant $\mathrm{pH}$ values.

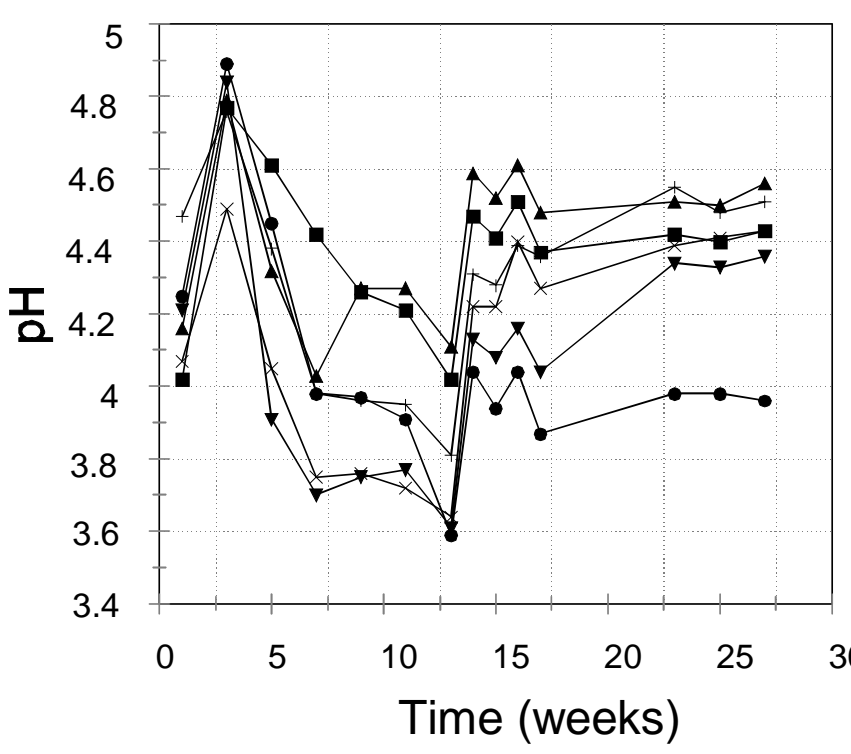

Figure 1

Changes in leachate $\mathrm{pH}$ of Microcosm 1 (+), $2(\mathbf{\nabla}), 3(\boldsymbol{\bullet}), 4(\boldsymbol{X}), 5$ $(\bullet)$ and $6(\bullet)$ packed as detailed in Table 1

\section{Heavy metals}

The activated sewage sludge was spiked with heavy metal salts prior to packing. One hundred $\mathrm{mg} \cdot \mathrm{f}^{-1}$ (refuse : sludge ratio 4.1:1) and $\left.200 \mathrm{mg} \cdot\right|^{-1}$ (refuse : sludge ratio 4.1:2) each of nickel $\left(\mathrm{Ni}^{2+}\right)$ sulphate, zinc $\left(\mathrm{Zn}^{2+}\right)$ sulphate, cupric $\left(\mathrm{Cu}^{2+}\right)$ chloride and chromium $\left(\mathrm{Cr}^{3+}\right)$ chloride were dissolved in the sludge supernatant.

\section{Refuse control microcosms}

For Microcosm 5, $200 \mathrm{mg} \cdot \mathrm{l}^{-1}$ of each of the four heavy metal salts was dissolved in distilled water $\left(\mathrm{dH}_{2} \mathrm{O}\right)$ prior to addition while $\mathrm{dH}_{2} \mathrm{O}$ alone was added to Microcosm 6 .

\section{Increases in heavy metal loadings}

The loadings of Microcosms 1,3 and 5 were increased from week 11 by applying heavy metal salt solutions $(30 \mathrm{ml}, 4.1: 1 ; 60 \mathrm{ml}$, 4.1:2) at an irrigation rate of $10 \mathrm{ml} \cdot \mathrm{h}^{-1}$ at each dosage point by means of plastic syringes $(20 \mathrm{ml})$ fitted with hypodermic needles.

The concentrations added to each of the microcosms for each metal were as follows: $150 \mathrm{mg} \cdot \mathrm{l}^{-1}$, Microcosm 1 and $300 \mathrm{mg} \cdot \mathrm{I}^{-1}$, Microcosms 3 and 5, week 11;200 mg. $\left.\right|^{-1}$, Microcosm 1 and $400 \mathrm{mg} \cdot \mathrm{l}^{-1}$,

\section{Redox potential}

The redox potential of leachate samples was determined with a combined platinum redox electrode (Crison) connected to a Crison MicropH 2002 meter. A ferrous/ferric solution was used to standardise the redox electrode before and after analysis. The standard solution contained $\left(\mathrm{g} \cdot \mathrm{l}^{-1} \mathrm{dH}_{2} \mathrm{O}\right)$ : ferrous ammonium sulphate, 39.21; ferric ammonium sulphate, 48.22; and concentrated sulphuric acid, 56.2 I. The redox reading of this solution averaged $+468 \mathrm{mV}$.

\section{Heavy metals}

A Varian Spectra AA-200 atomic absorption spectrophotometer (AAS) with a nitrous oxide-acetylene flame, to minimise chemical interferences, was used. The conditions for each metal analysis 30 were as follows: $\mathrm{Cr}^{3+}$ : wavelength, $357.9 \mathrm{~nm}$; spectral band pass, $0.2 \mathrm{~nm}$; lamp current, $7 \mathrm{~mA}$; $\mathrm{Cu}^{2+}$ : wavelength, $324.7 \mathrm{~nm}$; spectral band pass, $0.5 \mathrm{~nm}$; lamp current, $4 \mathrm{~mA}$; $\mathrm{Ni}^{2+}$ : wavelength, 232.9 $\mathrm{nm}$; spectral band pass, $0.2 \mathrm{~nm}$; lamp current, $4 \mathrm{~mA}$; and $\mathrm{Zn}^{2+}$ : wavelength, $213.9 \mathrm{~nm}$; spectral band pass, $0.1 \mathrm{~nm}$; lamp current, 5 $\mathrm{mA}$. Prior to analysis, each supernatant sample was filtered through an $0.45 \mu \mathrm{m}$ cellulose acetate membrane filter.

To determine the initial concentrations of $\mathrm{Cr}, \mathrm{Cu}, \mathrm{Ni}$ and $\mathrm{Zn}$, refuse and sewage sludge (supernatant and solids) samples were centrifuged in a Beckman J2 HS Centrifuge at $10000 \mathrm{r} \cdot \mathrm{min}^{-1} \mathrm{x} g$ for $25 \mathrm{~min}$. Thereafter, the supernatants were analysed.

The residual solids were then oven-dried at $60{ }^{\circ} \mathrm{C}$ for $72 \mathrm{~h}$. Approximately $1.0 \mathrm{~g}$, to the nearest mg, of each of the dried samples was transferred into a wide-form porcelain crucible. After ashing in a pre-heated furnace at $500{ }^{\circ} \mathrm{C}$ for $2 \mathrm{~h}$ and cooling, the residuals were moistened with $\mathrm{dH}_{2} \mathrm{O}$ and $10 \mathrm{ml}$ of $4 \mathrm{M} \mathrm{HCl}(32 \% \mathrm{v} / \mathrm{v}) / \mathrm{HNO}_{3}$ $(70.5 \% \mathrm{v} / \mathrm{v})$ acid mixture was added.

Digestion (at $163 \pm 5^{\circ} \mathrm{C}$ ) on a sand bath followed for $20 \mathrm{~min}$. The preparations were then transferred quantitatively to $100 \mathrm{ml}$ volumetric flasks with a glass rod to prevent losses and were diluted to volume with $\mathrm{dH}_{2} \mathrm{O}$. Filtration through $3.0 \mu \mathrm{m}$ cellulose acetate membrane filters followed. Thereafter, the crucibles and the precipitates on the filters were washed with $\mathrm{dH}_{2} \mathrm{O}$. The digested sample supernatants were then analysed by AAS.

\section{Results}

The moisture content of the refuse and sewage sludge was $45.5 \%$ $(\mathrm{m} / \mathrm{m})$ and $89 \%(\mathrm{~m} / \mathrm{m})$, respectively. 


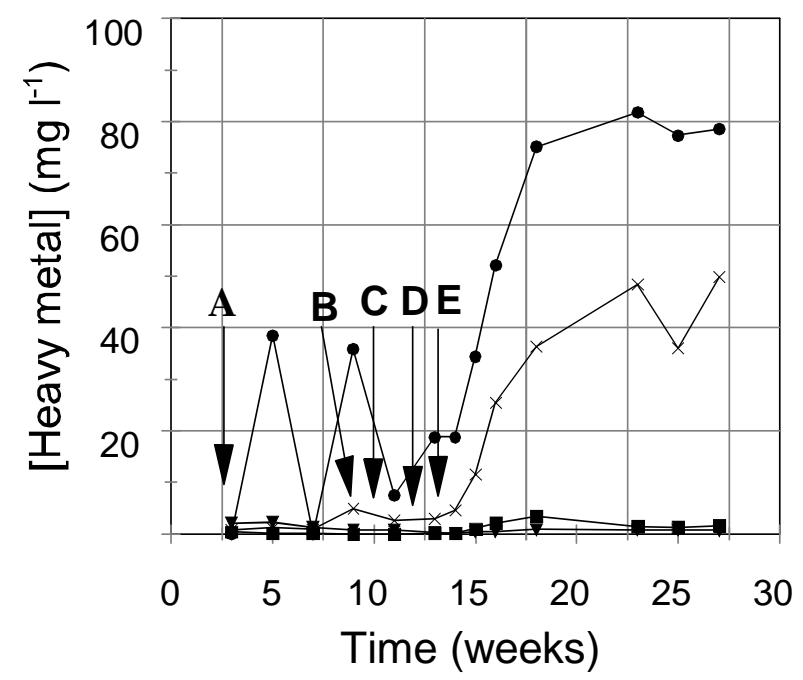

Figure 2

Changes in leachate $\mathrm{Cr}(\boldsymbol{\bullet}), \mathrm{Cu}(\mathbf{\nabla}), \mathrm{Ni}(\boldsymbol{X})$ and $\mathrm{Zn}(\bullet)$ concentrations of Microcosm 5 (a), 1 (b) and 3 (c) following metal supplementations of $100 \mathrm{mg} \cdot \mathrm{l}^{-1}(\mathrm{~A}), 150 \mathrm{mg} \cdot \mathrm{l}^{-1}$ (B), $200 \mathrm{mg} \cdot \mathrm{r}^{-1}$ (C), $400 \mathrm{mg} \cdot \mathrm{r}^{-1}$ (D) and 800 $\mathrm{mg} \cdot \cdot^{-1}$ (E) for Microcosm 1 and $100 \mathrm{mg} \cdot \cdot^{-1}(\mathrm{~A})$, $300 \mathrm{mg} \cdot \cdot^{-1}$ (B), $400 \mathrm{mg} \cdot \mathrm{l}^{-1}$ (C), $800 \mathrm{mg} \cdot \mathrm{l}^{-1}$ (D) and $1600 \mathrm{mg} \cdot \mathrm{H}^{-1}$ (E) for Microcosms 3 and 5

pH

Low pH values (<4.9) (Fig. 1) were recorded during the 27-week study period. The synthetic refuse used facilitated the production of volatile fatty acids (VFA) in the solid-state fermentations (Barlaz et al., 1989) which, in turn, affected the $\mathrm{pH}$. The presence of heavy metals did not facilitate the low $\mathrm{pH}$ values due to heavy metal toxicity and, specifically, the inactivation of hydrogen sinks as the unspiked columns (Microcosms 2,4 and 6) exhibited the same trends.

\section{Redox potential (E)}

The redox potentials recorded did not approach the optimum for the solid-state refuse methanogenic fermentation and were in the range of +2 to $+170 \mathrm{mV}$ (data not shown). The metal-spiked and nonspiked microcosms recorded comparable leachate redox potentials.

The precipitation of metal species relies on the aqueous biodegradation of refuse. Newton (1977), Pohland and Gould (1980) and Pohland et al. (1982) concluded that sulphide precipitation may be the ultimate control for many heavy metals in refuse. In the present study, sulphide precipitation probably did not contribute to metal immobilisation as the high $\mathrm{E}$ values recorded excluded sulphate reduction which is operated at $E$ values of \pm-220 $\mathrm{mV}$ (Atlas, 1984). Also, the low $\mathrm{pH}$ values (Fig.1) obviated other precipitations since an alkaline $\mathrm{pH}$ is required to facilitate hydroxide, oxide and carbonate precipitation (Gadd, 1986).
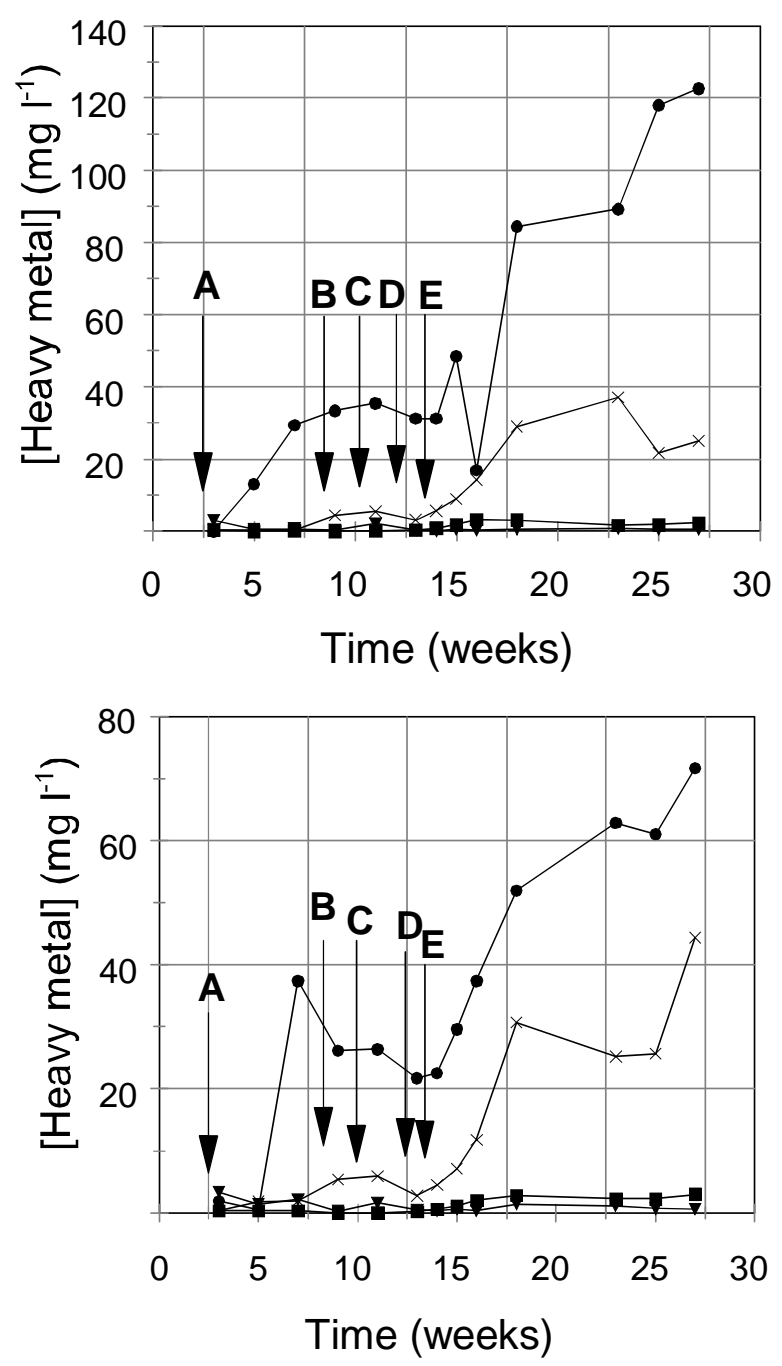

Heavy metal mobility and immobilisation

\section{Refuse microcosms}

Microcosms 5 and 6 leached Ni masses (Figs. 2a and 3a) of $2.71 \mathrm{mg}$ and $0.43 \mathrm{mg}$ of their totals of $271.95 \mathrm{mg}$ and $21.95 \mathrm{mg}$, respectively (Table 2). For Microcosm 5, an increase was observed following the second supplementation, but a marked increase was particularly evident after it received the 5th metal loading at week 15 (Fig. 2a). Although this microcosm received a total loading of $250 \mathrm{mg},>99 \%$ immobilised compared to $98.04 \%$ in Microcosm 6 . The Ni holding capacity of the refuse was not exceeded by the loading increases.

Higher $\mathrm{Cu}$ concentrations were measured in the leachate of Microcosm 5 (total mass leached $0.15 \mathrm{mg}, \sim 0.06 \%$ ) than Microcosm $6(0.06 \mathrm{mg}, \sim 1.01 \%)$. Following each of the first four $\mathrm{Cu}$ loadings, progressive leachate concentration reductions resulted, probably due to adsorption. The total leachate masses of $\mathrm{Cr}$ were comparable for the two microcosms $(0.15 \mathrm{mg}, \sim 0.05 \%$ and $0.17 \mathrm{mg}, \sim 0.68 \%$ for Microcosms 5 and 6, respectively) (Figs. 2a and 3a). For both metals equal masses $(0.15 \mathrm{mg})$ were displaced from Microcosm 5 , although the total loading of $\mathrm{Cr}(274.85 \mathrm{mg})$ was higher than the equivalent $(255.93 \mathrm{mg}$ ) for $\mathrm{Cu}$ (Table 2).

The total Zn leached in the 27 weeks of operation of Microcosm 6 was $17.55 \mathrm{mg}$ while the initial mass in the refuse was $64.98 \mathrm{mg}$. In contrast, for Microcosm 5, $6.23 \mathrm{mg}$ were leached from a total loading of $314.98 \mathrm{mg}$. The mass of the metal leached from the 
TABLE 2

$\mathrm{Cr}, \mathrm{Cu}, \mathrm{Ni}$ and $\mathrm{Zn}$ mass $(\mathrm{mg})$ of the solid and liquid fractions of refuse and sewage sludge, total heavy metal loadings applied $(\mathrm{mg})$, metals released $(\mathrm{mg})$ and percentages not immobilised for each microcosm

\begin{tabular}{|c|c|c|c|c|}
\hline & Chromium & Copper & Nickel & Zinc \\
\hline \multicolumn{5}{|l|}{ Initial mass } \\
\hline \multicolumn{5}{|l|}{ Synthetic refuse: } \\
\hline Supernatant & 0 & 2.45 & 4.95 & 12.23 \\
\hline Solid & 24.85 & 3.49 & 17.0 & 52.75 \\
\hline Total: & 24.85 & 5.94 & 21.95 & 64.98 \\
\hline \multicolumn{5}{|l|}{ Sewage sludge: } \\
\hline Supernatant & 0.003 & 0.02 & 0.013 & 0.01 \\
\hline Solid & 26.63 & 20.06 & 18.31 & 373.65 \\
\hline Total: & 26.63 & 20.08 & 18.32 & 373.66 \\
\hline Total (refuse plus sludge): & 51.48 & 26.02 & 40.27 & 438.64 \\
\hline \multicolumn{5}{|l|}{ Heavy metal loadings: } \\
\hline Microcosm $1(4.1: 1)$ & 65.7 & 65.7 & 65.7 & 65.7 \\
\hline Microcosms 3,5 (4.1:2) & 250 & 250 & 250 & 250 \\
\hline \multicolumn{5}{|l|}{ Microcosm 1} \\
\hline Total initial mass & 51.48 & 26.02 & 40.27 & 438.64 \\
\hline Heavy metal loading & 65.7 & 65.7 & 65.7 & 65.7 \\
\hline Mass leached & 0.2 & 0.13 & 1.88 & 7.85 \\
\hline$\%$ not immobilised & $\sim 0.17$ & $\sim 0.14$ & $\sim 1.77$ & $\sim 1.56$ \\
\hline \multicolumn{5}{|l|}{ Microcosm 2} \\
\hline Total initial mass & 51.48 & 26.02 & 40.27 & 438.64 \\
\hline Mass leached & 0.08 & 0.06 & 0.21 & 1.5 \\
\hline$\%$ not immobilised & $\sim 0.16$ & $\sim 0.23$ & $\sim 0.52$ & $\sim 0.34$ \\
\hline \multicolumn{5}{|l|}{ Microcosm 3} \\
\hline Total initial mass & 51.48 & 26.02 & 40.27 & 438.64 \\
\hline Heavy metal loading & 250 & 250 & 250 & 250 \\
\hline Mass leached & 0.81 & 0.17 & 2.01 & 5.41 \\
\hline$\%$ not immobilised & $\sim 0.27$ & $\sim 0.06$ & $\sim 0.69$ & $\sim 0.79$ \\
\hline \multicolumn{5}{|l|}{ Microcosm 4} \\
\hline Total initial mass & 51.48 & 26.02 & 40.27 & 438.64 \\
\hline Mass leached & 0.07 & 0.08 & 0.19 & 1.46 \\
\hline$\%$ not immobilised & $\sim 0.14$ & $\sim 0.31$ & $\sim 0.47$ & $\sim 0.33$ \\
\hline \multicolumn{5}{|l|}{ Microcosm 5 (Control) } \\
\hline Total initial mass (refuse) & 24.85 & 5.93 & 21.95 & 64.98 \\
\hline Heavy metal loading & 250 & 250 & 250 & 250 \\
\hline Mass leached & 0.15 & 0.15 & 2.71 & 6.23 \\
\hline$\%$ not immobilised & $\sim 0.05$ & $\sim 0.06$ & $\sim 0.99$ & $\sim 1.98$ \\
\hline \multicolumn{5}{|l|}{ Microcosm 6 (Control) } \\
\hline Total initial mass (refuse) & 24.85 & 5.93 & 21.95 & 64.98 \\
\hline Mass leached & 0.17 & 0.06 & 0.43 & 17.55 \\
\hline$\%$ not immobilised & $\sim 0.68$ & $\sim 1.01$ & $\sim 1.96$ & $\sim 27$ \\
\hline
\end{tabular}

loaded microcosm was lower than that of the control microcosm as was also apparent for $\mathrm{Cr}$ (Table 2).

\section{Co-disposal microcosms}

Leached Ni progressively increased in both the metal-dosed microcosms (Microcosms 1 and 3) (Figs. 2b,c) and similar increases were recorded in the unspiked microcosms (Microcosms 2 and 4) (Figs. 3b, c). The leached masses were $1.88 \mathrm{mg}$, $2.01 \mathrm{mg}, 0.21 \mathrm{mg}$ and $0.19 \mathrm{mg}$ of their total masses of $105.97 \mathrm{mg}, 290.27 \mathrm{mg}, 40.27 \mathrm{mg}$ and $40.27 \mathrm{mg}$, respectively (Table 2). Microcosm 1 received a total spiking of $65.7 \mathrm{mg}$ and $~ 98.23 \%$ immobilised compared to Microcosm 3 which received $250 \mathrm{mg}$ with > 99\% immobilised. Elevated $\mathrm{Cr}$, Ni and $\mathrm{Zn}$ concentrations were measured in the leachates of the metal-dosed microcosms (Microcosms 1 and 3) (Figs. 2b, c) after week 15 while similar increases were detected in the unspiked microcosms (Microcosms 2 and 4) (Figs. 3b, c).

For $\mathrm{Cu}$, the total displaced never exceeded $0.17 \mathrm{mg}$ (Microcosm 3 ) of the total mass $(91.72 \mathrm{mg}$, Microcosm 1; $276.02 \mathrm{mg}$, Microcosm 3; and $26.02 \mathrm{mg}$, Microcosms 2 and 4). Thus, it appeared that the $\mathrm{Cu}$-holding capacity was not exceeded. $\mathrm{Cr}$ showed similar trends. In the metal-dosed microcosms, $\sim 0.17 \%$ and $\sim 0.27 \%$ remained in solution in Microcosms 1 and 3 (Figs. 2b, c), respectively. In the unspiked microcosms (Microcosms 2 and 4) (Figs. 3b,c) $\sim 0.16 \%$ and $\sim 0.14 \%$ were not immobilised. The total displaced $\mathrm{Cr}$ of Microcosm 3 was $0.81 \mathrm{mg}$ of the total mass (301.48 mg).

Zn showed distinct displacement increases with recorded leachate concentrations $>118 \mathrm{mg} \cdot \mathrm{l}^{-1}$ (Weeks 25 - 27) and $>60 \mathrm{mg} \cdot \mathrm{l}^{-1}$ (Weeks 23 - 27) for Microcosms 1 and 3, respectively (Figs. 2b,c). Higher total masses were recorded in the leachates of Microcosms 1 and $3(7.85 \mathrm{mg}, \sim 1.56 \%$ and $5.41 \mathrm{mg}, \sim 5.4 \%$ of $504.34 \mathrm{mg}$ and $688.64 \mathrm{mg}$, respectively) compared with Microcosms 2 and $4(1.5 \mathrm{mg}, \sim 0.34 \%$ and $1.64 \mathrm{mg}, \sim 0.33 \%$ of $438.64 \mathrm{mg}$, respectively).

The possibility existed that the prolonged acidic conditions favoured free cations since it has been reported that an acid $\mathrm{pH}$ and high $\mathrm{E}$ facilitate increased metal solubility (Wood and Wang, 1983). Since metal adsorption is usually enhanced at neutral $\mathrm{pH}$ (Ferris et al., 1989), the low $\mathrm{pH}$ trends recorded (Fig. 1) did not favour immobilisation. Despite this, the masses of $\mathrm{Cr}$, $\mathrm{Cu}, \mathrm{Ni}$ and $\mathrm{Zn}$ displaced from Microcosm 3 were low compared with the original loadings (Table 2).

\section{Refuse vs co-disposal microcosms}

Comparing the heavy metal concentrations of the leachate of Microcosms 5 and 6 (Figs. 2a and 3a) and the co-disposal columns (Microcosms 1 to 4) 
(Figs. 2b,c and 3b,c), no distinct differences were detected in the metal-dosed microcosms for $\mathrm{Cr}$ and $\mathrm{Cu}$. For each, an initial $\mathrm{Cu}$ peak was followed by a progressive decrease despite the increased loadings. When the percentages of $\mathrm{Cu}$ leached from the microcosms are taken into account $(\sim 0.14 \%$, Microcosm $1 ; \sim 0.06 \%$, Microcosm $3 ; \sim 0.06 \%$, Microcosm 5) (Table 2) it is apparent that the refuse/ sludge $\mathrm{Cu}$ binding capacity was not exceeded. Ni exhibited higher mobility than $\mathrm{Cu}$ and $\mathrm{Cr}(\sim 1.77 \%$, Microcosm $1 ; \sim 0.69 \%$, Microcosm 3; 0.99\%, Microcosm 5).

The unspiked refuse microcosm (Microcosm 6) (Fig. 3a) and unspiked co-disposal microcosms (Microcosms 2 and 4) (Figs. $3 \mathrm{~b}, \mathrm{c})$ recorded variable masses of displaced $\mathrm{Cr}, \mathrm{Cu}$ and $\mathrm{Ni}$ and these variabilities were even more pronounced for $\mathrm{Zn}$. It should be noted, however, that although the masses of $\mathrm{Zn}$ displaced were high, the immobilised masses were also high. This was particularly evident in Microcosm 6 where $73 \%$ immobilised while $17.55 \mathrm{mg}$ of the total mass of $64.98 \mathrm{mg}$ leached.

Comparing the $\mathrm{Zn}$ concentrations in the leachates of Microcosms 1, 3 and 5 (Figs. 2 a,b,c) similar trends were observed ( 98.44\%, $\sim 99.21 \%$ and $\sim 98.02 \%$ immobilised while $7.85 \mathrm{mg}, 5.41 \mathrm{mg}$ and $6.23 \mathrm{mg}$ of the total masses of $504.34 \mathrm{mg}, 688.64 \mathrm{mg}$ and 314.98 mg leached) (Table 2).

As sewage sludge was excluded from the controls, the cationexchange capacity (MacNicol and Beckett, 1989) was probably reduced. In this study the presence of sludge appeared to have a minimal effect on heavy metal retention compared with the refuse microcosms.

\section{Discussion}

Factors such as the leachate $\mathrm{pH}$ and redox potential, waste type and age, waste surface properties and the effects of changing surface properties during fermentation are responsible for heavy metal immobilisation, mobilisation and precipitation as insoluble sulphides in co-disposal landfill sites. In this investigation, unbalanced fermentations developed with acidogenesis > acidotrophy (Ehlers et al., 1999). It was very difficult to identify any possible bactericidal/ bacteriostatic effects of the added metals.

When the metals were added via sewage sludge or in solution, extensive retention occurred, even at low $\mathrm{pH}$ values. For $\mathrm{Ni}$ and $\mathrm{Zn}$, elevated leachate concentrations were still accompanied by extensive retention. Metal displacements via leachate showed relatively consistent patterns which could be attributed possibly to the metalholding capacity of the refuse and/or sewage sludge for a specific metal, i.e. the cation exchange preference for one metal species compared with another.

As the behaviour of any one metal may be changed by its chemical and biological environment, a strict ranking would be unjustified on the basis of the data available, but the general order of retention appeared to be: $\mathrm{Cr}>\mathrm{Cu}>\mathrm{Ni} \approx \mathrm{Zn}$.

Dual co-disposal of activated sewage sludge plus heavy metalcontaining wastewaters with refuse could be advantageous since studies with sludges have shown little enhancement of leachate metal concentrations (Knox,1989). Sewage sludge co-disposal per $s e$ could be advantageous if the heavy metal adsorption capacity of the refuse is exceeded as the solid-state fermentation progresses. It could also be disadvantageous, however, if the elevated adsorbed concentrations are displaced in response to acidogenesis.

Thus, one important aspect of heavy metal co-disposal that is the focus of an ongoing investigation is the status of the solid-state fermentation and the effect that it has on metal retention and mobilisation. The onset and progress of the fermentation should affect metal mobilisation as waste surface characteristics and the
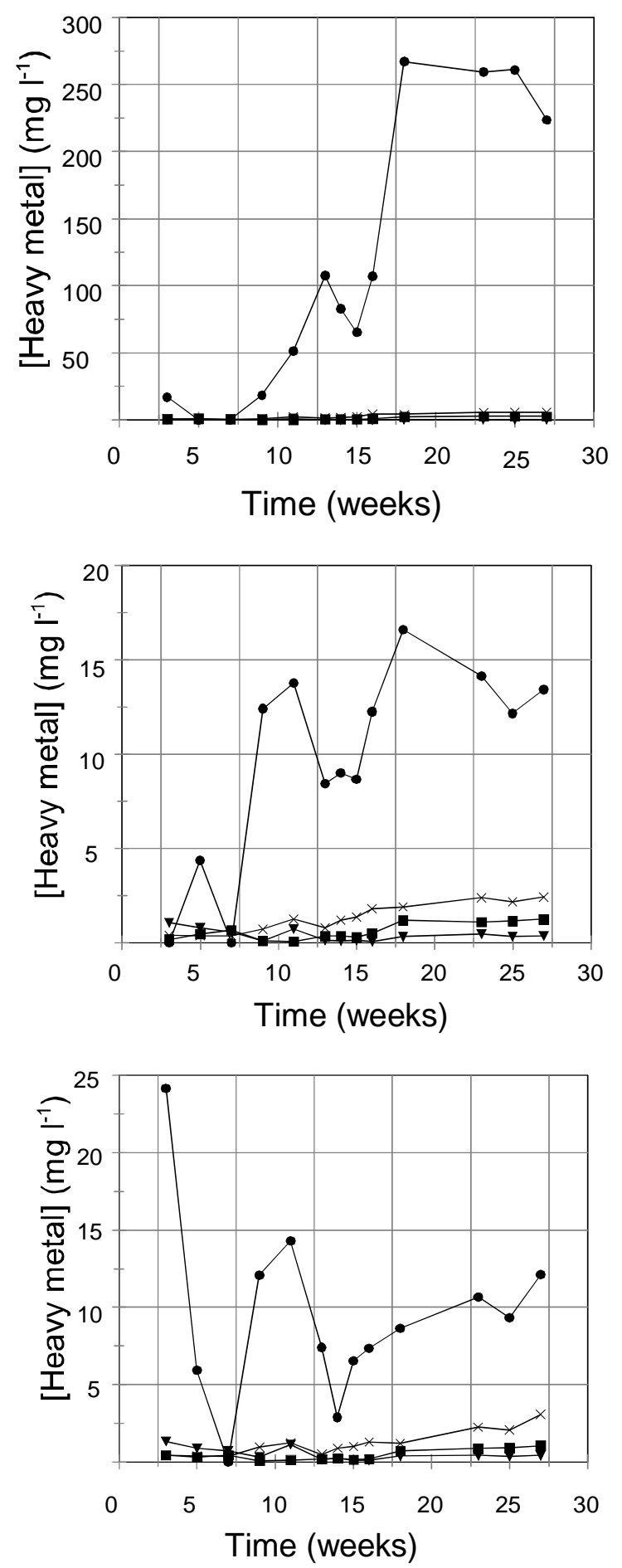

Figure 3

Changes in leachate $\mathrm{Cr}(\boldsymbol{\bullet}), \mathrm{Cu}(\boldsymbol{\nabla}), \mathrm{Ni}(\boldsymbol{X})$ and $\mathrm{Zn}(\bullet)$ concentrations of Microcosm 6 (a), 2 (b) and 4 (c)

changes of surface properties should contribute to metal displacement.

\section{Acknowledgements}

This research was sponsored by the National Research Foundation (NRF) and the University of Natal whose financial support is gratefully acknowledged. 


\section{References}

ATLAS RM (1984) Microbiology: Fundamentals and Applications. MacMillan, New York

BABICH H and STOTZKY G (1985) Heavy metal toxicity to microbemediated ecological processes: A review and potential application to regulatory policies. Environ. Res. 36 111-137.

BARLAZ MA, SCHAEFER DM and HAM K (1989) Bacterial population development and chemical characteristics of refuse decomposition in a simulated sanitary landfill. Appl. Environ. Microbiol. 55 55-65.

CHAPELLE FH (1993) Ground-Water Microbiology and Geochemistry. John Wiley and Sons, New York.

EHLERS GAC, DANEEL RA and SENIOR E (1999) An investigation of nutrient limitation in single (activated sewage sludge) and dual (phenol/ activated sewage sludge) co-disposals with refuse. J. Chem. Technol. Biotechnol. 74 1045-1054.

FERRIS FG, SCHULTZE S, WITTEN TC, FYFE WS and BEVERIDGE TJ (1989) Metal interactions with microbial biofilms in acidic and neutral pH environments. Appl. Environ. Microbiol. 55 1249-1257.

FLETCHER P and BECKETT PHT (1987) The chemistry of heavy metals in digested sewage sludge-II. Heavy metal complexation with soluble organic matter. Water Res. 21 1153-1161.

GADD GM (1986) Fungal response towards heavy metals. In: Herber RA and Codd GA (eds.) Microbes in Extreme Environments. Academic Press, London. 83-110.

GREGSON SK, ROBERTS RD and Roberts JM (1988) The fate of heavy metals in co-disposed refuse. Environ. Technol. Lett. 9 983-990.
KNOX K (1989) A Review of Technical Aspects of Co-Disposal. A Report Prepared for the UK Department of the Environment. Nottingham, UK Department of the Environment.

MACNICOL RD and BECKETT PHT (1989) The distribution of heavy metals between the principal components of digested sludge. Water Res. 23199-206.

MUELLER RF and STEINER A (1992) Inhibition of anaerobic digestion caused by heavy metals. Water Sci.Technol. 26 835-846.

NEWTON JR (1977) Pilot-scale studies of the leaching of industrial waste in simulated landfills. Water Poll. Control 76 368-478.

PERCIVAL LJ (1996) An Investigation of the Affects of Dual Co-Disposal of a Phenol Wastewater and Activated Sewage Sludge with Refuse and Treatment of High-Strength Leachate Obtained from a Closed CoDisposal Landfill. M.Sc. Thesis, Univ. of Natal.

PERCIVAL LJ and SENIOR E (1998) An assessment of the effects of dual co-disposal of phenol and waste activated sewage sludge with refuse on the refuse anaerobic fermentation and leachate quality. Water SA 24 57-70.

POHLAND FG and GOULD JP (1980) Stabilization of municipal landfill containing industrial wastes. Proc. EPA 6th Ann. Res. Symp. on Disposal of Hazardous Waste EPA-600/9-80-010. 360-371.

POHLAND FG, GOULD JP, RAMSEY E and WALTERS DC (1982). The behaviour of heavy metals during landfill disposal of hazardous waste.Proc. EPA 8thAnn. Res. Symp. on Landfill Disposal of Hazardous Waste EPA-600/9-82-002, 360-371.

WOOD JM and WANG HK (1983) Microbial resistance to heavy metals. Environ. Sci. Technol. 17 582A-590A. 